\title{
Recombinant protein production associated growth inhibition results mainly from transcription and not from translation
}

\author{
Zhaopeng $\mathrm{Li}^{1}$ and Ursula Rinas ${ }^{1,2^{*}}$ (B)
}

\begin{abstract}
Background: Recombinant protein production can be stressful to the host organism. The extent of stress is determined by the specific properties of the recombinant transcript and protein, by the rates of transcription and translation, and by the environmental conditions encountered during the production process.

Results: The impact of the transcription of the T7-promoter controlled genes encoding human basic fibroblast growth factor (hFGF-2) and green fluorescent protein (GFP) as well as the translation into the recombinant protein on the growth properties of the production host E. coli BL21(DE3) were investigated. This was done by using expression vectors where the promoter region or the ribosome binding site(s) or both were removed. It is shown that already transcription without protein translation imposes a metabolic burden on the host cell. Translation of the transcript into large amounts of a properly folded protein does not show any effect on cell growth in the best case, e.g. highlevel production of GFP in Luria-Bertani medium. However, translation appears to contribute to the metabolic burden if it is connected to protein folding associated problems, e.g. inclusion body formation.
\end{abstract}

Conclusion: The so-called metabolic burden of recombinant protein production is mainly attributed to transcription but can be enhanced through translation and those processes following translation (e.g. protein folding and degradation, heat-shock responses).

Keywords: Escherichia coli, Recombinant protein production, Metabolic burden, Transcriptional burden

\section{Background}

The most common E. coli-based expression system is the bacteriophage T7 RNA polymerase and T7 promoter controlled gene expression combination. IPTGinduction of the chromosomally encoded bacteriophage T7 RNA polymerase leads to high level expression of T7 promoter-controlled genes and correspondingly high recombinant protein titers. High level recombinant protein production in Escherichia coli frequently leads to an impact on host cell metabolism detectable through

*Correspondence: Ursula.Rinas@helmholtz-hzi.de

2 Helmholtz Centre for Infection Research, Inhoffenstraße 7,

38124 Brunswick, Germany

Full list of author information is available at the end of the article growth retardation and generally known as "metabolic burden" $[1,2]$. The factors contributing to the metabolic burden are multifaceted depending on the host/vector combination and on the properties of the encoded gene with its transcription and translation products as well as on the environmental conditions encountered during the production process [3-6]. The prime reasons for the protein production related metabolic burden have been attributed to protein translation and protein folding [1, 6] as well as to transcription and plasmid amplification related processes [7-9]. However, production of the same protein under identical conditions in the same host/vector combination but with single codon exchanges can change the metabolic perturbations considerably [10-13] 
suggesting that the phenomenon is even more complex than anticipated.

In this contribution we analyze the impact of T7-promoter-controlled recombinant gene expression on the host cell metabolism using two different model proteins, the difficult-to-fold human basic fibroblast growth factor (hFGF-2) with its high propensity to form inclusion bodies in E. coli and the easy-to-fold green fluorescent protein (GFP) mainly produced as soluble protein. For both examples we generated a set of expression vectors in which either the ribosome binding site (RBS) or the promoter region or both were removed in order to analyze if the plasmid itself, the transcription of the recombinant gene, the translation into the protein product and/or protein folding related processes have an impact on host cell metabolism.

\section{Results}

\section{Different proteins induce different growth inhibitions}

The production of recombinant proteins can impair cellular growth detectable through a slower increase in cell mass or even complete growth inhibition, slower carbon substrate uptake, and reduced respiratory activity. The extent of this inhibition is strongly influenced by the properties of the recombinant protein, a phenomenon noticeable when different proteins are being produced in the same host strain/expression system combination under identical production conditions (Fig. 1). For example, the production of $\mathrm{hFGF}-2$, a protein partly produced as soluble protein and partly in form of inclusion bodies, leads to a strong impact on bacterial growth ([14-16], Fig. 1a). On the other hand, production of the green fluorescent protein (GFP), mainly produced as soluble protein in $E$. coli, impairs bacterial growth only marginally (Fig. 1b). Although this protein is produced in larger amounts at identical conditions compared to hFGF-2, production of GFP leads to a less severe decline of growth and metabolic activities (Fig. 1).

To distinguish if recombinant protein synthesis and/ or transcription of the recombinant gene are responsible for the growth inhibitory effect a set of modified expression vectors was constructed. All expression vectors carried a gene encoding a recombinant protein (hFGF-2 or GFP) with the original T7-based production vectors containing in front of the target gene the $\mathrm{T} 7$ promoter and a ribosome binding site (RBS). One set of expression vectors was modified in such a way that transcription of the recombinant gene was allowed by IPTG addition but translation into the protein product omitted by removal of the RBS. In a second set of expression vectors the promoter region was removed to prevent transcription of the recombinant gene. And in a third set of expression vectors the promoter region as well as the RBS were removed.

\section{Already transcription of the recombinant gene causes growth inhibition}

Cells of E. coli BL21(DE3) transformed with these different types of plasmids carrying the gene encoding hFGF-2 were grown in shake flask cultures in complex Luria-Bertani medium as well as in defined glucosesupplemented mineral salt medium and cell growth was followed after IPTG addition (Fig. 2). Cells carrying the production vectors with intact promoter region and RBS revealed the expected growth inhibition in both types of media (Fig. 2a, b). Cells carrying the plasmids without RBS but intact promoter region also revealed growth inhibition upon IPTG addition showing that already enhanced recombinant gene transcription without recombinant protein synthesis negatively impacts cell growth (Fig. 2a, b). However, in both types of media the growth inhibition was intensified when hFGF-2 was produced. SDS-PAGE analyses verified the presence of hFGF-2 in induced cells carrying the production vector with intact promoter region and RBS and absence in those induced cells transformed with the expression vector where the RBS in front of the hFGF-2 gene was removed (Fig. 3). Compared to transcript levels of the tufA gene, encoding the major housekeeping protein and elongation factor EF-Tu, transcript levels of hFGF-2 were largely enhanced in both types of transformed cells, carrying the plasmid with intact promoter region with and without RBS, after induction in LB (Fig. 4a) as well as in defined medium (Fig. 4b). For example, in cells carrying the original expression vector and induced in LB medium hFGF-2 transcripts reached more than 2000 times higher levels than those from the tufA gene. Non-induced control cells and induced control cells transformed with the vectors where the promoter region in front of the hFGF-2 gene was removed did not produce hFGF-2 (Fig. 3) and only revealed basal transcripts levels of the plasmid-encoded hFGF-2 gene (Fig. 4). Induced control cells carrying expression vectors without intact promoter region and the induced host E. coli BL21(DE3) not carrying any expression vector revealed the same marginal almost undetectable growth inhibition compared to the non-induced cells (Fig. 2c, d) demonstrating that plasmid maintenance and constitutive expression of plasmid encoded (antibiotic resistance) genes do not lead to any growth inhibition. A marginal growth retardation can be attributed to induced expression and synthesis of the chromosomally encoded T7 RNA polymerase (Fig. 2d). 

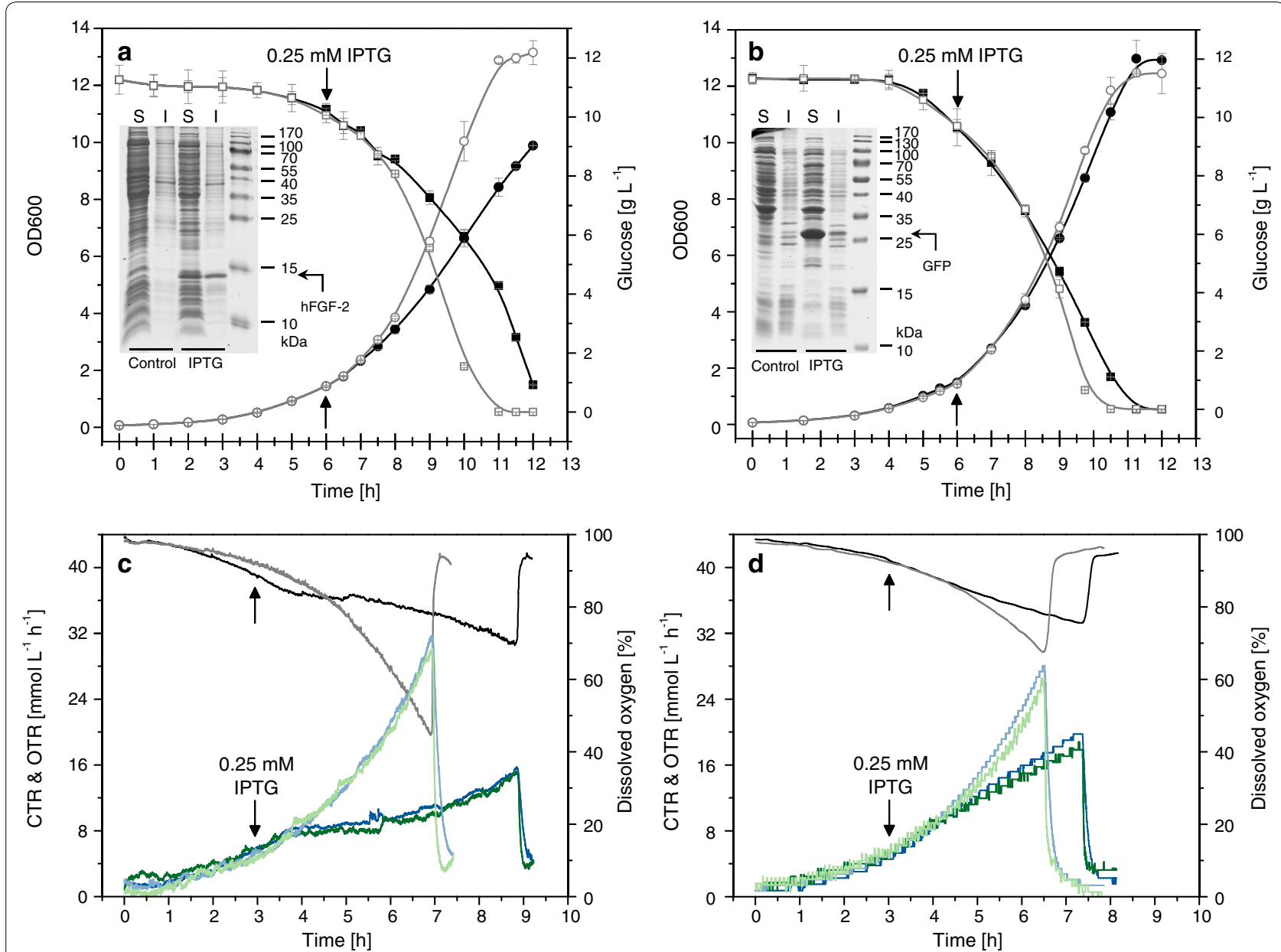

Fig. 1 Growth inhibition resulting from the production of different recombinant proteins. Production of $\mathbf{a}, \mathbf{c}$ hFGF-2 and $\mathbf{b}$, d GFP using E. coli BL21 (DE3) as expression host was carried out in $\mathbf{a}, \mathbf{b}$ Fernbach flasks with baffles and in $\mathbf{c}, \mathbf{d}$ bioreactor batch cultures employing a defined mineral salt medium with glucose as carbon substrate. a, b OD600 (circles), glucose (squares) and SDS-PAGE analysis of target protein production (S: soluble, and I: insoluble cell protein of control and producing cells, the positions of target proteins are indicated) are shown. $\mathbf{c}$, $\mathbf{d}$ Carbon dioxide (CTR, green lines) and oxygen transfer rates (OTR, blue lines) as well as dissolved oxygen concentrations (black and gray lines) are given. The arrows indicate the time point of IPTG addition to a final concentration of $0.25 \mathrm{mM}$ in production experiments. Dark colored symbols and lines correspond to production experiments. Light colored lines and open gray symbols correspond to control experiments where IPTG addition was omitted. Data are presented as mean $\pm \mathrm{SD}, \mathrm{n}=2$

\section{Recombinant protein translation itself does not cause growth inhibition}

In another set of experiments cells carrying the GFP encoding production vectors with intact promoter region (with and without RBS) were grown in shake flask cultures in complex Luria-Bertani medium as well as in defined glucose-supplemented mineral salt medium and cell growth was followed after IPTG addition (Fig. 5). These experiments revealed for cells carrying the production vector with intact promoter region and RBS the expected growth inhibition in both types of media, but less pronounced compared to hFGF-2 producing cells (Fig. 5a, b versus Fig. 2a, b).
Interestingly, cells carrying the plasmid without RBS but intact promoter region in front of the GFP gene revealed the same growth inhibition in LB medium upon IPTG addition as those cells transformed with the plasmid having the intact promoter region as well as the RBS (Fig. 5a) suggesting that only recombinant gene transcription but not protein translation itself contributes to growth inhibition. The presence and absence of the recombinant GFP in induced cells carrying the expression vector with and without RBS was proven by SDS-PAGE analysis, respectively (Fig. 6) as well as the presence of elevated GFP transcript levels in both types of transformed cells upon induction in LB medium 

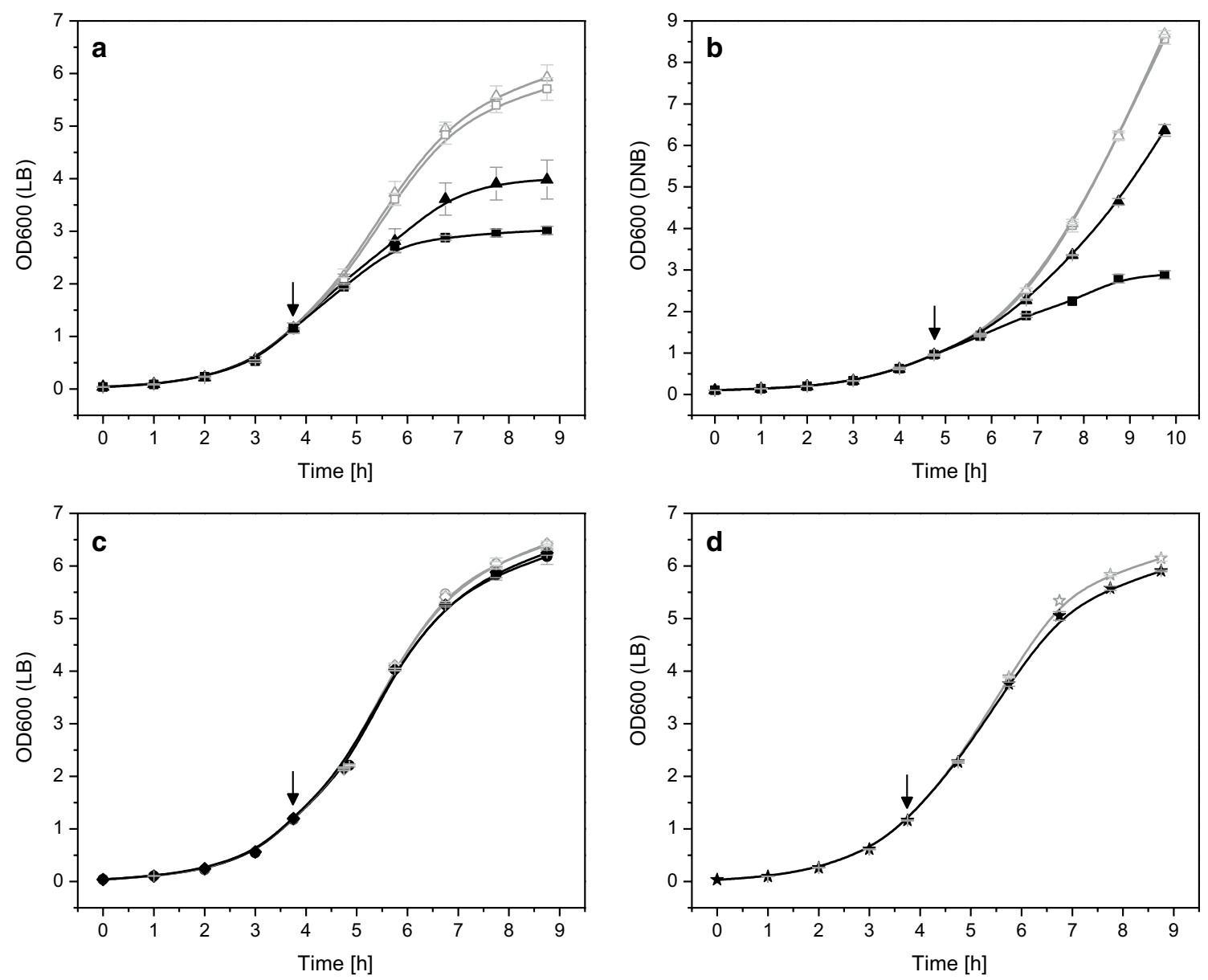

Fig. 2 Already transcription of the recombinant gene causes growth inhibition. Growth properties of E. coli BL21 (DE3) with expression vectors carrying the gene encoding hFGF-2 in shake-flask cultures with a Luria-Bertani (LB) or b defined glucose-supplemented mineral salt medium. Growth of cells carrying the original expression vector with promoter region and with RBS (squares) and the expression vector with promoter region but without RBS in front of the hFGF-2 gene (triangles). c Growth of cells on LB medium carrying the expression vector without promoter region but with RBS (circles) and without promoter region and without RBS (diamonds). $\mathbf{d}$ Control cultures of cells without any expression vector growing on LB medium (stars). Full black symbols always correspond to IPTG induced cultures and open gray symbols to cultures where IPTG addition was omitted. The time-point of IPTG addition to a final concentration of $0.5 \mathrm{mM}$ is indicated by an arrow. Data are presented as mean \pm SD, $n=4$

(Fig. 7). Thus, the data prove that transcription of the GFP gene contributes to growth inhibition, however, synthesis of the GFP protein in LB medium is without impact on cell growth.

\section{Recombinant protein folding associated problems contribute to growth inhibition}

During induction in defined glucose-supplemented mineral salt medium, however, cells carrying the GFP encoding expression vector with the intact promoter region as well as the RBS exhibited a higher growth inhibition than those cells carrying the plasmid with intact promoter region but without RBS (Fig. 5b). Again, SDSPAGE analyses revealed the presence of GFP in induced cells carrying the production vector with intact promoter region and RBS but not in those induced cells transformed with the expression where the RBS was removed (Fig. 6). Also, real-time PCR analysis proved the presence of GFP mRNA in both types of transformed cells (Fig. 7). Thus, synthesis of recombinant GFP protein in defined glucose-supplemented mineral salt medium augments the recombinant gene transcription mediated growth inhibition.

SDS-PAGE analysis of the soluble and insoluble cell fraction of E. coli BL21(DE3) producing either hFGF-2 or GFP on complex Luria-Bertani or glucose-supplemented mineral salt medium revealed that on both types of media the majority of hFGF-2 aggregates into inclusion 


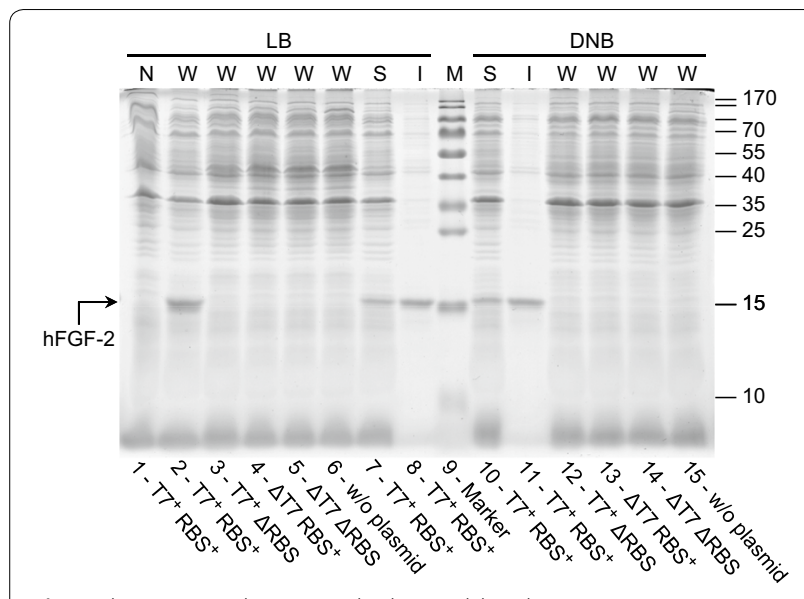

Fig. 3 hFGF-2 production only detectable when promoter region and RBS are present. SDS-PAGE analysis of IPTG induced cells carrying the gene encoding hFGF-2 growing on LB medium (lanes 1-8) and glucose supplemented mineral salt medium DNB (lanes 10-15) collected $4 \mathrm{~h}$ after induction. Lane 1: $\mathrm{N}_{1} \mathrm{~T}^{+}{ }^{+} \mathrm{RBS}^{+}$(non-induced control, total cell extract of cells containing the expression vector with promoter and with RBS in front of the hFGF-2 gene), lane 2:W, $\mathrm{T7}^{+} \mathrm{RBS}^{+}$(induced cells with promoter and with RBS), lanes 3, 12: W, $\mathrm{T}^{+} \triangle \mathrm{RBS}$ (with promoter but without RBS), lanes 4, 13: W, $\triangle \mathrm{T} 7 \mathrm{RBS}^{+}$ (without promoter but with RBS), lanes $5,14: \mathrm{W}, \triangle \mathrm{T} 7 \triangle \mathrm{RBS}$ (without promoter and without RBS), lanes 6, 15: W, w/o plasmid (induced $E$. coli BL21(DE3) without expression vector), lanes 7, 10: S, $\mathrm{T7}^{+} \mathrm{RBS}^{+}$ (soluble) and lanes $8,11: 1, \mathrm{T7}^{+} \mathrm{RBS}^{+}$(insoluble cell fraction of induced cells containing the expression vector with promoter and with RBS). Lane 9: molecular mass marker, the position of hFGF-2 is indicated by an arrow. N: non-induced whole cell protein W: induced whole cell protein, S: induced soluble part, and I: induced insoluble part of whole cell protein bodies (Fig. 3). GFP, on the other hand, does not form aggregates during growth on Luria-Bertani medium (Fig. 5). However, during production on glucose-supplemented mineral salt medium also GFP aggregates partly into inclusion bodies although the majority of the protein is still found in the soluble cell fraction (Fig. 6). These findings show that transcription of the recombinant gene clearly contributes to the metabolic burden but recombinant protein translation only if it is connected of protein folding associated problems, e.g. formation of inclusion bodies.

\section{Growth inhibition also caused by induction of the "empty" expression vector}

Finally, the growth properties of E. coli BL21(DE3) carrying the "empty" expression vector pET28c or pET29c were analyzed. Short transcripts with a RBS are encoded downstream of the T7 promoter (pET28c: 225 bp encoding a protein of $8.3 \mathrm{kDa}$ and pET29c: $225 \mathrm{bp}$ encoding a protein of $8.5 \mathrm{kDa}$ ). Surprisingly, both transformants showed a strong growth inhibition upon IPTG induction even stronger than the hFGF-2 producing stain (Fig. 8, data only shown for pET28c). SDS-PAGE analysis of induced cells revealed a protein at the expected position in E. coli BL21(DE3):pET29c mainly found in the insoluble cell fraction (data not shown). However, no protein band was found in induced E. coli BL21(DE3):pET28c at the expected molecular mass of $8.3 \mathrm{kDa}$ (data not shown) suggesting stalled ribosomes or proteolytic degradation of the encoded peptide. Cells carrying pET28c
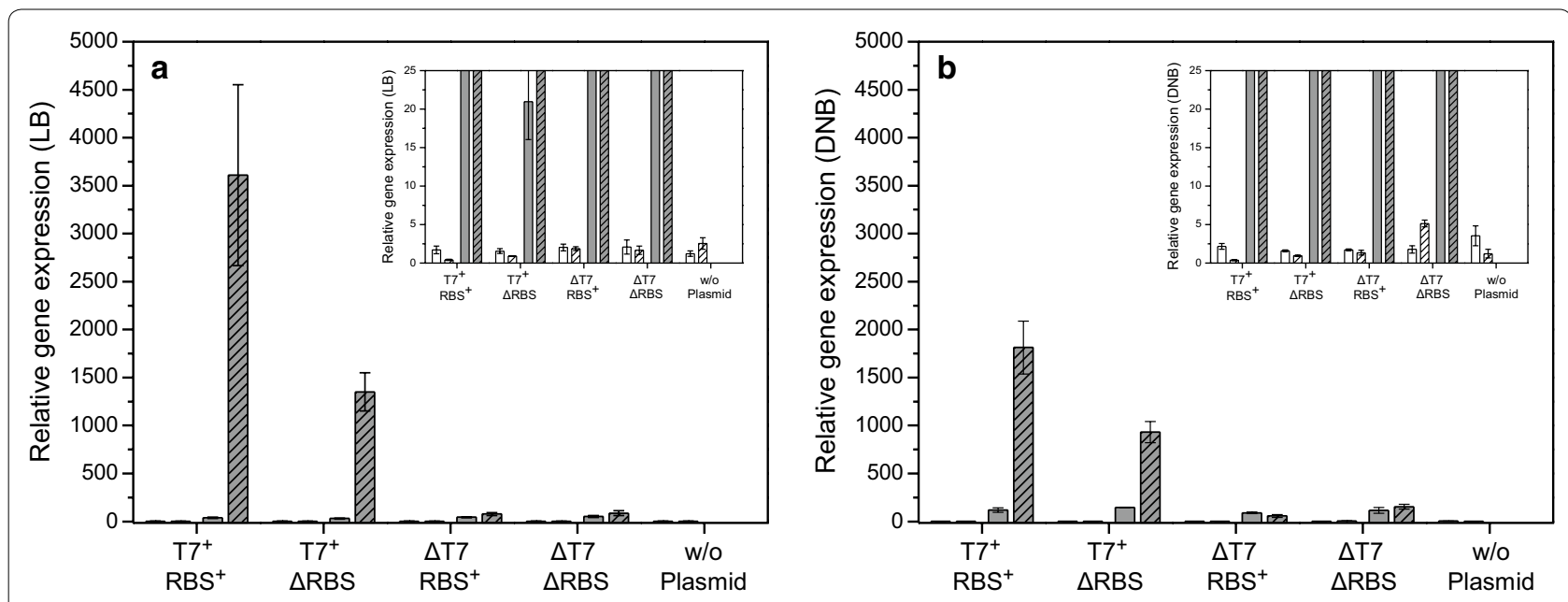

Fig. 4 hFGF-2 transcript levels under inducing and non-inducing conditions. a Transcript levels in E. coli BL21 (DE3) transformed with expression vectors carrying the gene encoding hFGF-2 in shake-flask cultures with a Luria-Bertani (LB) medium or b defined glucose-supplemented mineral salt medium (DNB). Trancripts of genes encoding the major elongation factor EF-Tu (white bars) and hFGF-2 (gray bars) are shown in non-induced cells (open bars) and $4 \mathrm{~h}$ after IPTG induction (hatched bars). $T 7^{+} \mathrm{RBS}^{+}$: cells containing the expression vector with promoter and with RBS in front of the hFGF-2 gene; $T 7^{+} \triangle \mathrm{RBS}$ : with promoter but without RBS; $\triangle T 7 \mathrm{RBS}^{+}$: without promoter but with RBS; $\triangle T 7 \triangle \mathrm{RBS}$ : without promoter and without RBS; w/o plasmid: E. coli BL21(DE3) without expression vector. The inserts depict the same data as the main figures only at different scale. Transcripts of $r$ rs $\mathrm{H}$, were used as internal standard and artificially defined as 10,000. Data are presented as mean $\pm S D, n=4$ 

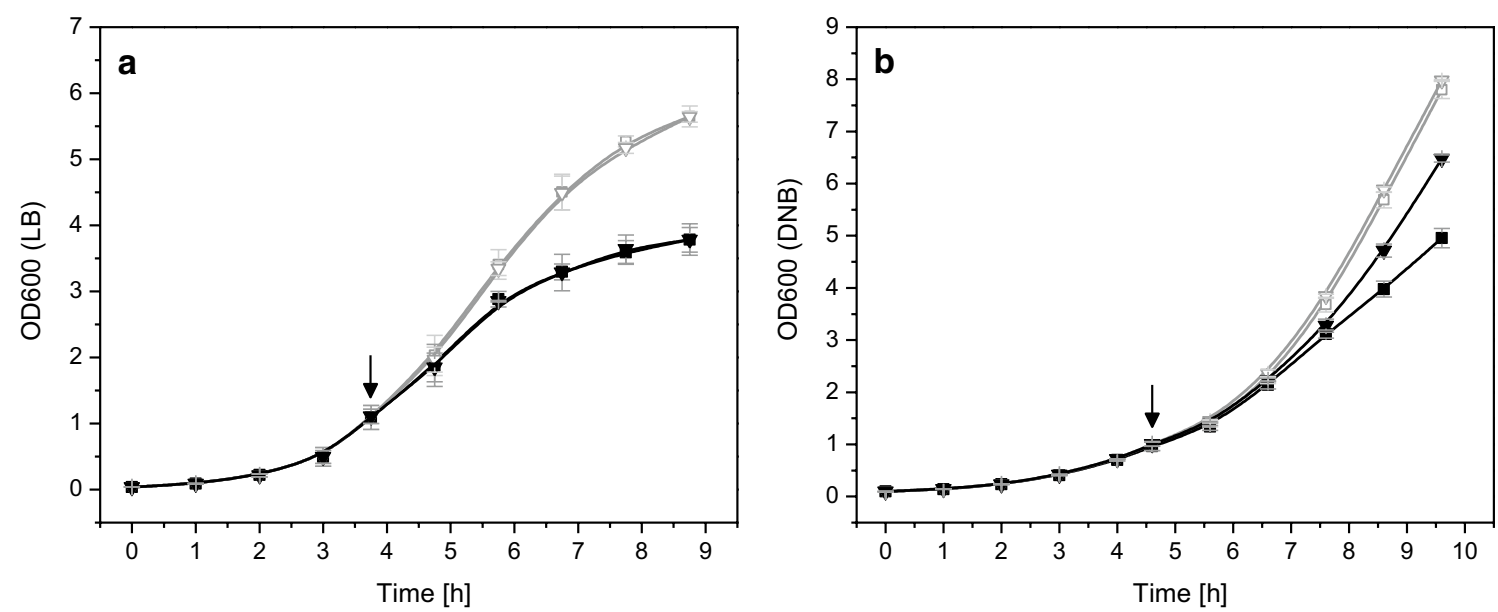

Fig. 5 Recombinant protein translation itself does not impair cell growth but folding associated problems contribute to growth inhibition. a Growth properties of E. coli BL21(DE3) with expression vectors carrying the gene encoding GFP in shake-flask cultures with a Luria-Bertani medium or $\mathbf{b}$ defined glucose-supplemented mineral salt medium (DNB). Growth of cells carrying the original expression vector with promoter region and with RBS (squares) and the expression vector with promoter region but without RBS in front of the hFGF-2 gene (triangles). Full black symbols always correspond to IPTG induced cultures and open gray symbols to cultures where IPTG addition was omitted. The time-point of IPTG addition to a final concentration of $0.5 \mathrm{mM}$ is indicated by an arrow. Data are presented as mean $\pm S D, n=4$

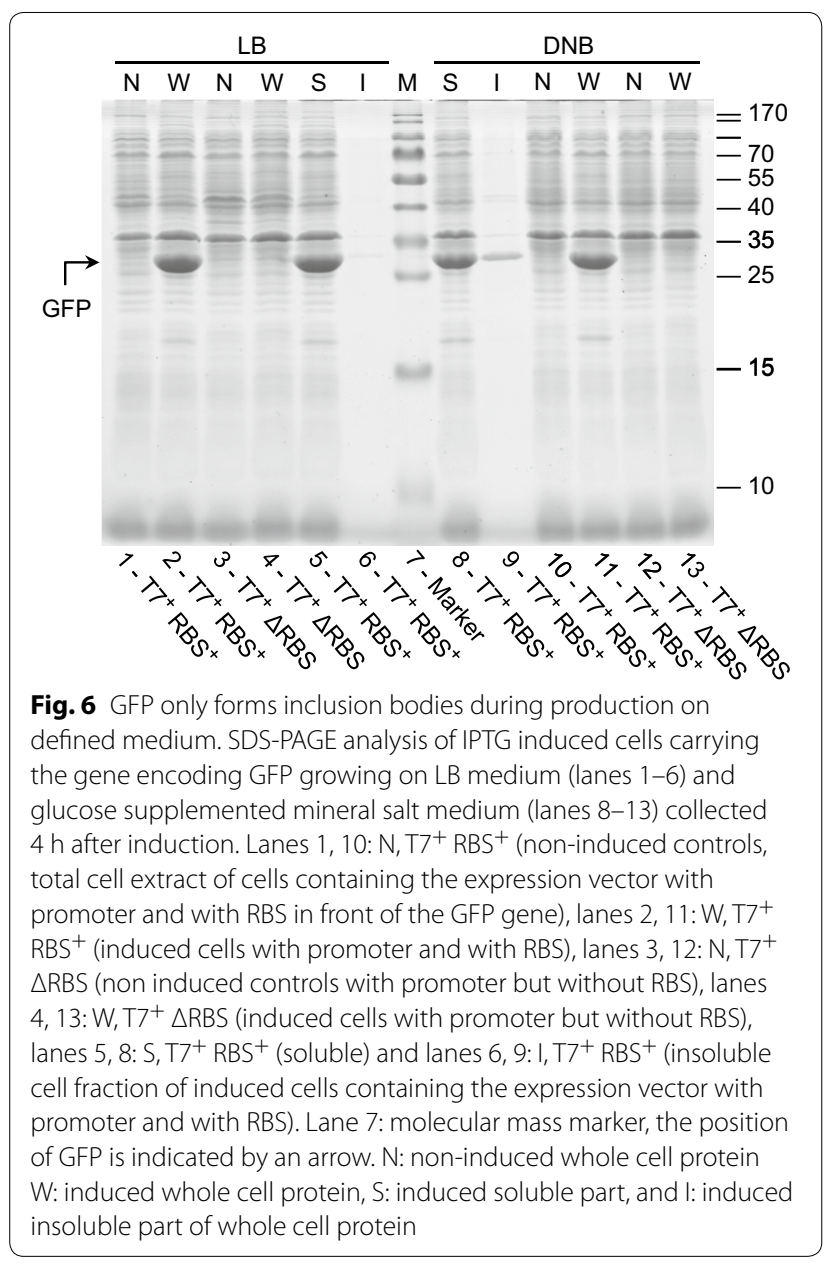

without RBS but intact promoter region still showed strong growth inhibition upon IPTG addition but not as strong as the original pET28c vector with RBS (there is no additional RBS present in the short transcript) (Fig. 8). These data show that also short transcripts originating from "empty" expression vectors cause growth inhibition which can be intensified through corresponding downstream-processes of transcription (e.g. stalled ribosomes, folding problems of the translated protein peptide involving aggregation, degradation and the accompanying heat shock response).

\section{Discussion}

Reduction of the recombinant protein production associated metabolic burden is generally accomplished by decreasing the expression of the recombinant gene. A sometimes detrimental growth inhibition with low levels of the target protein can be overcome, for example, by replacing multicopy plasmids through chromosomal integration of the target gene $[8,9]$ or by utilizing strains/ constructs with reduced target gene promoter activity $[13,17,18]$. All these attempts reduce recombinant gene expression, alleviate the metabolic burden and at the same time increase the target protein amount. These findings suggest that not the amount of the recombinant protein but rather recombinant gene transcription, the mRNA level or even the speed of translation are the major sources for the metabolic burden. Our data show that transcription or the transcript contributes to the metabolic burden but not protein translation itself. 


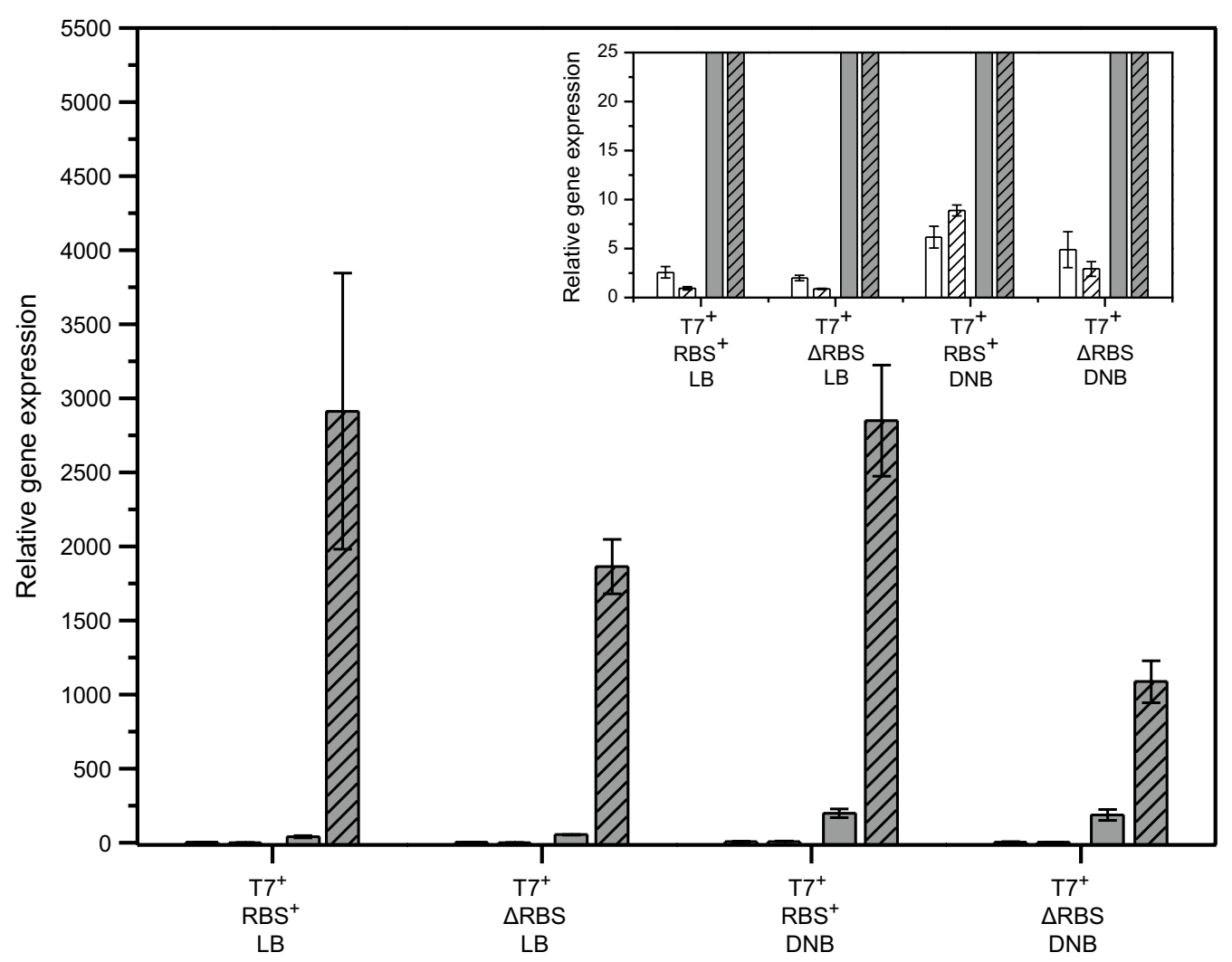

Fig. 7 GFP transcript levels under inducing and non-inducing conditions. Transcript levels in E. coli BL21(DE3) transformed with expression vectors carrying the gene encoding GFP in shake-flask cultures with Luria-Bertani (LB) medium or defined glucose-supplemented mineral salt medium (DNB). Trancripts of genes encoding the major elongation factor EF-Tu (white bars) and GFP (gray bars) are shown in non-induced cells (open bars) and $4 \mathrm{~h}$ after IPTG induction (hatched bars). $\mathrm{T7}^{+} \mathrm{RBS}^{+}$: cells containing the expression vector with promoter and with RBS in front of the GFP gene; $\mathrm{T7}^{+} \triangle \mathrm{RBS}$ : with promoter but without RBS. The insert depicts the same data set as the main figure only at different scale. Transcripts of rrs $H$ were used as internal standard and artificially defined as 10,000. Data are presented as mean $\pm S D, n=4$

Recombinant protein synthesis appears to add only to the metabolic burden if it is connected to protein folding related problems during production, e.g. inclusion body formation, proteolytic degradation and connected cell responses such as heat shock responses. In the best case, e.g. high-level production of GFP on LB medium, translation of the transcript into a properly folded protein does not show any effect on cell growth. This proves that elevated translation of a useless protein-a highly energy consuming process-does not have a compulsatory negative effect on host cell growth. But a negative effect is clearly exerted through elevated transcription or elevated transcript levels. On the other hand, translation or those processes following translation can enhance the transcription related growth inhibition. In this case it might not always be possible to clearly assign this additional inhibitory effect to translation (e.g. stalled ribosomes [19]) or to processes following translation of the target protein e.g. inclusion body formation, proteolytic degradation and/or connected cell responses such as heat shock responses. Moreover, the effect can also be combinatorial, e.g. translation is too fast for a slow folding protein leading to the formation of inclusion bodies, and subsequently to an enhanced growth inhibition. This is presumably the case for hFGF-2. hFGF-2 is a slow folding protein [20] that readily forms inclusion bodies and elicits a strong heat-shock response during rapid production in batch cultures [16] this way most likely increasing the transcription related growth inhibition.

After attributing the recombinant protein production related "metabolic burden" originally more to protein synthesis related problems more evidence is nowadays accumulating that transcription or the transcript itself is the major factor of the recombinant protein production related growth inhibition. Recent studies on the production of proteins with synonymous codons revealed that some codons, encoding the same amino acid, were inhibiting cell growth more severely than others $[12,13]$. It was also shown that the toxicity of certain gene variants was only dependent on transcription but independent on 


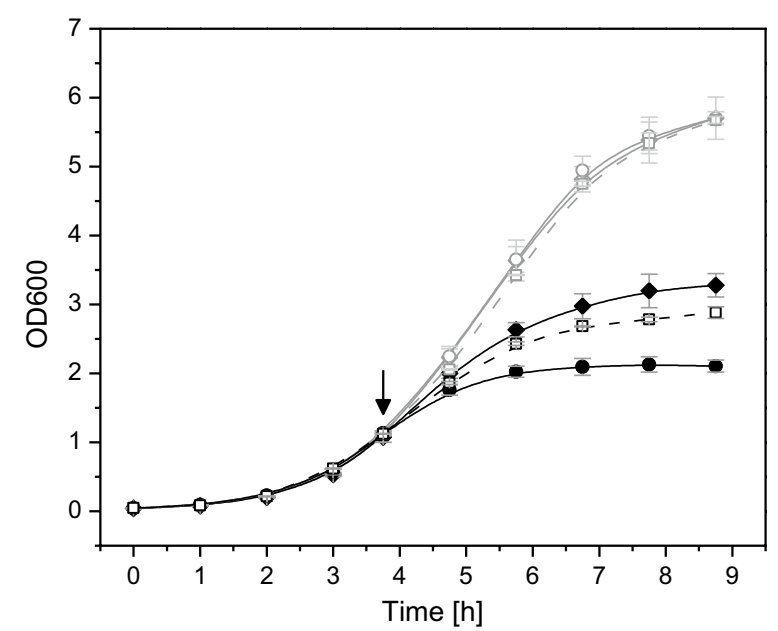

Fig. 8 Growth properties of E. coli BL21 (DE3) carrying the "empty" pET-28c expression vector. Cells carrying the original "empty" $\mathrm{pET}-28 \mathrm{c}$ expression vector with promoter region and RBS (circles) and the "empty" vector with promoter region but without RBS (diamonds) were grown in shake flask cultures in Luria-Bertani medium. Growth of cells carrying the original expression vector encoding hFGF-2 with promoter region and with RBS is revisited for a better comparison (broken lines, open squares). Black symbols always correspond to IPTG induced cultures and gray symbols to cultures where IPTG addition was omitted. The time-point of IPTG addition to a final concentration of $0.5 \mathrm{mM}$ is indicated by an arrow. Data are presented as mean $\pm S D, n=4$

protein translation [13]. Moreover, it was found that the toxicity of certain mRNA sequences could not be related to plasmid abundance nor to the abundance of the encoded mRNA [13]. Mittal et al. concluded that toxic RNA might interact with essential cellular components and interfere with their normal function through a mechanism not yet known [13]. Our findings are in line with the observation that certain mRNA elements impose a stronger metabolic burden than others and additionally show that excessive transcription or elevated amounts of recombinant mRNA in general lead to growth retardation although not necessarily to severe growth inhibition.

\section{Materials and methods \\ Strain and plasmids}

Escherichia coli BL21 (DE3) (Novagen, Germany) harboring the plasmids pET-29c-hFGF-2 [15] and pET-28cHis6-GFP [21] were used for the production of hFGF-2 and GFP, respectively. Both genes are codon-optimized and their sequences given in Knoerzer et al. [22] and Crameri et al. [23]. The codon adaptation index (CAI) was determined as 0.79 for hFGF-2 and 0.65 for GFP [24]. The modified plasmids with deletions of RBS site and/or T7 promoter region (Table 1) were constructed using Q $5^{\circledR}$ Site-Directed Mutagenesis Kit (New England Biolabs, USA). NEBaseChanger ${ }^{\mathrm{TM}}$ tool (New England Biolabs, USA) was used to design primer sequences and infer annealing temperatures. The detailed experimental conditions were according to manufacturer's instructions. Sequences of parental and mutant plasmids were confirmed by Sanger sequencing (Microsynth Seqlab, Germany).

\section{Medium and cultivation conditions}

The composition of Luria-Bertani (LB) broth was as follows: $10 \mathrm{~g} \mathrm{~L}^{-1}$ tryptone, $5 \mathrm{~g} \mathrm{~L}^{-1}$ yeast extract, and $5 \mathrm{~g} \mathrm{~L}^{-1} \mathrm{NaCl}$. The $\mathrm{pH}$ was adjusted to $\mathrm{pH} 7$ by $\mathrm{NaOH}$ before autoclaving. For solidification, $15 \mathrm{~g} \mathrm{~L}^{-1}$ agar were added. The composition of the defined glucose-supplemented mineral salt medium (Defined Non-inducing Broth (DNB) [21]) was as follows: $12 \mathrm{~g} \mathrm{~L}^{-1}$ glucose $\cdot \mathrm{H}_{2} \mathrm{O}$, $1.2 \mathrm{~g} \mathrm{~L}^{-1} \mathrm{MgSO}_{4} \cdot 7 \mathrm{H}_{2} \mathrm{O}, 4 \mathrm{~g} \mathrm{~L}^{-1}\left(\mathrm{NH}_{4}\right)_{2} \mathrm{HPO}_{4}, 13.3 \mathrm{~g} \mathrm{~L}^{-1}$ $\mathrm{KH}_{2} \mathrm{PO}_{4}, 1.7 \mathrm{~g} \mathrm{~L}^{-1}$ citric acid. $\mathrm{H}_{2} \mathrm{O}, 100.8 \mathrm{mg} \mathrm{L}{ }^{-1} \mathrm{Fe}(\mathrm{III})$ citrate, $2.1 \mathrm{mg} \mathrm{L} \mathrm{Na}_{2} \mathrm{MoO}_{4} \cdot 2 \mathrm{H}_{2} \mathrm{O}, 1.4 \mathrm{mg} \mathrm{L}^{-1} \mathrm{CoCl}_{2}$, $12.3 \mathrm{mg} \mathrm{L}{ }^{-1} \mathrm{MnCl}_{2} \cdot 2 \mathrm{H}_{2} \mathrm{O}, 1.2 \mathrm{mg} \mathrm{L}^{-1} \mathrm{CuCl}_{2}, 3 \mathrm{mg} \mathrm{L}^{-1}$ $\mathrm{H}_{3} \mathrm{BO}_{3}, 33.8 \mathrm{mg} \mathrm{L}^{-1} \mathrm{Zn}\left(\mathrm{CH}_{3} \mathrm{COOH}\right)_{2} \cdot 2 \mathrm{H}_{2} \mathrm{O}, 14.1 \mathrm{mg} \mathrm{L}^{-1}$ Titriplex III. The pH was adjusted at $\mathrm{pH} 6.8$ by $\mathrm{NaOH}$. Details of medium preparation are given elsewhere [21].

Table 1 Plasmids

\begin{tabular}{ll}
\hline Plasmids & Features \\
\hline pET-28c/pET-29c & Novagen, Germany \\
pET-28c $\triangle$ RBS & Mutant plasmid with deletion of all RBSs (AAGGAG) between T7 promoter and T7 terminator \\
pET-29c-hFGF-2 & Parental plasmid for the production of hFGF-2 [15] \\
pET-29c-hFGF-2 $\triangle$ RBS & Mutant plasmid with deletion of all RBSs (AAGGAG) between T7 promoter and T7 terminator \\
pET-29c-hFGF-2 $\triangle T 7$ & Mutant plasmid with deletion of T7 promoter region (TAATACGACTCACTATAGG) \\
pET-29c-hFGF-2 $\triangle$ RBS \& $\triangle$ T7 & Mutant plasmid with deletion of all RBSS (AAGGAG) between T7 promoter and T7 terminator \\
pET-28c-His6-GFP & as well as T7 promoter region (TAATACGACTCACTATAGG) \\
pET-28c-His6-GFP $\triangle \mathrm{RBS}$ & Parental plasmid for the production of GFP [21] \\
\hline
\end{tabular}


For plasmid maintenance, $50 \mathrm{mg} \mathrm{L}^{-1}$ kanamycin were added to the medium.

Precultures were prepared essentially as described previously [21]: briefly, a single colony from LB agar plate was transferred to LB medium after overnight incubation at $30{ }^{\circ} \mathrm{C}$. The cultures were shaken at $30{ }^{\circ} \mathrm{C}$ overnight to inoculate the LB main cultures or at $30{ }^{\circ} \mathrm{C}$ for $6 \mathrm{~h}$ to inoculate the DNB overnight pre-cultures. DNB pre-cultures were used to inoculate the DNB main cultures. Shake flask cultivations were carried out using 1.8 L Fernbach flasks with three baffles containing $200 \mathrm{~mL}$ medium at $30{ }^{\circ} \mathrm{C}$ and $180 \mathrm{rpm}$ or $500 \mathrm{~mL}$ Erlenmeyer flasks containing $50 \mathrm{~mL}$ medium at $30{ }^{\circ} \mathrm{C}$ and $250 \mathrm{rpm}$ using a shaker with an amplitude of $5 \mathrm{~cm}$. During bioreactor batch cultivations temperature, $\mathrm{pH}$, aeration, and agitation speed were set at $30{ }^{\circ} \mathrm{C}, \mathrm{pH} 6.9,1.5 \mathrm{vvm}$ and $300 \mathrm{rpm}$, respectively. All cultures were IPTG-induced at mid-exponential phase when the optical density reached OD600 1.0-1.5. All cultivations were carried out at least in quadruplicate if not stated otherwise. Mean values and standard deviation are given.

\section{Basic analytical procedures and calculations}

Cell growth was monitored by measurement of the absorbance at $600 \mathrm{~nm}$ (OD600). For glucose analysis, the YSI 2300 STAT PlusTM glucose and lactate analyzer (YSI Life Sciences, USA) was used. Off-gas analysis was performed in bioreactor cultures using the BlueInOne gas analyzer (BlueSens, Germany). The carbon dioxide and oxygen transfer rates were calculated as described previously [25]. The dissolved oxygen concentration was determined using a polarographic dissolved oxygen sensor (Mettler Toledo, Germany). For preparation of cell extracts and determination of soluble and insoluble product fractions, cells were disrupted by BugBuster ${ }^{\mathrm{TM}}$ Protein Extraction Reagent (Novagen, USA) with rLysozyme and Benzonase according to manufacturer's instructions. Soluble and insoluble cell fractions were separated by centrifugation at $17,000 \mathrm{~g}$ and $4{ }^{\circ} \mathrm{C}$ for $30 \mathrm{~min}$. SDS-PAGE analysis was performed in the Mini-PROTEAN Tetra Cell (Bio-Rad, USA) according to standard procedures and manufacturer's instructions. After electrophoresis, proteins were visualized by colloidal Coomassie G-250 staining [26].

\section{RNA extraction}

Cultivation samples were transferred to centrifuge tubes which were prefilled with an equal volume of inhibition solution $\left(5 \% \mathrm{H}_{2} \mathrm{O}\right.$ saturated phenol in ethanol). Cells were pelleted by centrifugation $\left(17,000 \mathrm{~g}\right.$ and $4{ }^{\circ} \mathrm{C}$ for $5 \mathrm{~min}$ ) and the supernatant was removed. The pellets were resuspended in half the original volume of RNAlater solution (25 mM sodium citrate, $\mathrm{pH}$ 5.2, 10 mM EDTA,
Table 2 Primers for qPCR

\begin{tabular}{llll}
\hline Gene & Primer sequence $\mathbf{5}^{\prime} \mathbf{- \mathbf { 3 } ^ { \prime }}$ & $\mathbf{T m}^{\prime}\left({ }^{\circ} \mathbf{C}\right)$ & Amplicon (bp) \\
\hline rrsh & Fw: TCAGCGGGGATGAAGGGAGTA & 58.0 & 209 \\
& AAG & & \\
& Rev: GCCAGTATCAGATGCAGTTCC & 57.4 & \\
& CAG & & \\
tufA & Fw: TTCTTCAAAGGCTACCGTCCGC & 57.1 & 211 \\
& Rev: GAACTTAGCAACAACGCCCGC & 58.1 & \\
hFGF-2 & Fw: AAGACCCGAACGTCTGTACTGC & 57.1 & 215 \\
& Rev: GGTAACGCATTTGGAGCCAGC & 57.1 & \\
GFP & Fw: TGGAAAACTACCTGTTCCCTGGC & 56.6 & 198 \\
& Rev: CCTTCAAACTTGACTTCAGCA & 57.3 & \\
& CGC & &
\end{tabular}

$700 \mathrm{~g} \mathrm{~L}^{-1}$ ammonium sulfate) and stored at $-70{ }^{\circ} \mathrm{C}$. Before hot phenol RNA extraction, cells stored in RNAlater solution were centrifuged at $17,000 \mathrm{~g}$ and $4{ }^{\circ} \mathrm{C}$ for $10 \mathrm{~min}$. After discarding the supernatant, the pellets were resuspended in $900 \mu \mathrm{L}$ DEPC-treated $\mathrm{H}_{2} \mathrm{O}$ with $400 \mathrm{U}$ $\mathrm{mL}^{-1}$ rLysozyme (Merck, Germany). After addition of $90 \mu \mathrm{L} 10 \%$ SDS, samples were incubated at $800 \mathrm{rpm}$ and $27{ }^{\circ} \mathrm{C}$ for $10 \mathrm{~min}$ and subsequently heated at $65{ }^{\circ} \mathrm{C}$ for 2 min. Afterwards, $100 \mu \mathrm{L} 1 \mathrm{M}$ sodium acetate, $\mathrm{pH} 5.2$ and $1 \mathrm{~mL} \mathrm{H} \mathrm{H}_{2} \mathrm{O}$ saturated phenol $(\mathrm{pH}<7)$ were added to the samples. Samples were inverted several times to mix and incubated at $65{ }^{\circ} \mathrm{C}$ for $7 \mathrm{~min}$. Every $40 \mathrm{~s}$, the samples were inverted several times. After centrifugation at $17,000 \mathrm{~g}$ and $4{ }^{\circ} \mathrm{C}$ for $15 \mathrm{~min}$, the aqueous top layer was transferred to a new tube. The same volume of chloroform was added. After complete mixing and subsequent centrifugation at $17,000 \mathrm{~g}$ and $4{ }^{\circ} \mathrm{C}$ for $10 \mathrm{~min}$, the aqueous top layer was again transferred to a new tube. To precipitate RNA, $100 \mu \mathrm{L} 5 \mathrm{M} \mathrm{NaCl}$ and $1-2 \mathrm{~mL}$ cold ethanol $\left(-20^{\circ} \mathrm{C}\right)$ were added. After centrifugation at $17,000 \mathrm{~g}$ and $4{ }^{\circ} \mathrm{C}$ for $20 \mathrm{~min}$, the RNA precipitate was washed once with $75 \%$ ethanol, centrifuged again at $17,000 \mathrm{~g}$ and $4{ }^{\circ} \mathrm{C}$ for $20 \mathrm{~min}$ and the supernatant was discarded. Air-dried RNA pellets were resuspended in nuclease-free water and stored at $-20^{\circ} \mathrm{C}$.

\section{cDNA synthesis}

$27 \mu \mathrm{L}$ reaction mixture containing $1 \mu \mathrm{g}$ of total RNA and $0.375 \mu \mathrm{g}$ of random hexamer primer was heated to $65^{\circ} \mathrm{C}$ for $5 \mathrm{~min}$ to melt secondary structure within the template. After cooling immediately on ice for $1 \mathrm{~min}, 4 \mu \mathrm{L}$ dNTPs (10 mM each), $1 \mu \mathrm{L}$ M-MLV reverse transcriptase (Promega, USA) and $8 \mu \mathrm{L} 5 \times$ Reaction Buffer were added to the reaction mixture. The reverse transcription was carried out at $37^{\circ} \mathrm{C}$ for $1 \mathrm{~h}$. The synthesized cDNA was stored at $-20^{\circ} \mathrm{C}$. 


\section{Quantitative real-time PCR}

qPCR primers (Table 2) were designed using Eurofins's online PCR primer design tools (https://www.eurofinsge nomics.eu/en/ecom/tools/pcr-primer-design/, Eurofins Genomics, Germany). qPCR was performed in an IQ5 Multicolor Real-Time PCR Detection System (BioRad, USA) using GoTaq ${ }^{\circledR}$ qPCR Master Mix (Promega, USA). Each $25 \mu \mathrm{L}$ reaction mixture contained $12.5 \mu \mathrm{L}$ of $2 \times$ qPCR Master Mix, $0.5 \mu \mathrm{L}$ cDNAs and $0.5 \mu \mathrm{L}$ of each primer. Amplification conditions were $3 \mathrm{~min}$ at $95^{\circ} \mathrm{C}$, followed by a three-steps cycle of denaturation at $95^{\circ} \mathrm{C}$ for $30 \mathrm{~s}$, annealing at $57.5^{\circ} \mathrm{C}$ for $30 \mathrm{~s}$ and extension at $72{ }^{\circ} \mathrm{C}$ for $30 \mathrm{~s}$ for a total of 50 cycles. All qPCR reactions were carried out in triplicate and mean values are given. $16 \mathrm{~S}$ ribosomal RNA ( $r r s H$ ) was used as the internal standard. Expressions of translation elongation factor EF-Tu $(t u f A)$, hFGF-2 and GFP genes were normalized to $\mathrm{rrsH}$, whose relative gene expression was artificially defined as 10,000 for a better comparison.

\section{Acknowledgements}

Not applicable.

\section{Authors' contributions}

ZL carried out the experiments and performed the data analysis and prepared a first draft of the manuscript. UR directed the study and prepared the final manuscript. Both authors read and approved the final manuscript.

\section{Funding}

Partial financial support was received from the German Ministry of Education and Research (BMBF) through the FORSYS-Partner program (Grant FKZ 0315285) and from the German Research Council (DFG) through the Cluster of Excellence "Rebirth"EXC62.

\section{Availability of data and materials}

All data generated or analyzed during this study are included in this published article.

\section{Ethics approval and consent to participate}

Not applicable.

\section{Consent for publication \\ Not applicable.}

\section{Competing interests}

The authors declare that they have no competing interests.

\section{Author details}

${ }^{1}$ Leibniz University of Hannover, Technical Chemistry-Life Science, Callinstr. 5, 30167 Hannover, Germany. ${ }^{2}$ Helmholtz Centre for Infection Research, Inhoffenstraße 7, 38124 Brunswick, Germany.

Received: 31 January 2020 Accepted: 26 March 2020

Published online: 06 April 2020

\section{References}

1. Bentley WE, Mirjalili N, Anderson DC, Davis R, Kompala DS. Plasmidencoded protein: the principal factor in the "metabolic burden" associated with recombinant bacteria. Biotechnol Bioeng. 1990;35:668-81.

2. Bhattacharya SK, Dubey AK. Metabolic burden as reflected by maintenance coefficient of recombinant Escherichia coli overpressing target gene. Biotechnol Lett. 1995;17:1155-60.
3. Lecina M, Sarro E, Casablancas A, Godia F, Cairo JJ. IPTG limitation avoids metabolic burden and acetic acid accumulation in induced fedbatch cultures of Escherichia coli M15 under glucose limiting conditions. Biochem Eng J. 2012;70:78-83.

4. Gubellini F, Verdon G, Karpowich NK, Luff JD, Boel G, Gauthier N, Handelman SK, Ades SE, Hunt JF. Physiological response to membrane protein overexpression in E. coli. Mol Cell Proteomics. 2011;10:M111.

5. Gasser B, Saloheimo M, Rinas U, Dragosits M, Rodríguez-Carmora E, Baumann K, Giuliani M, Parrilli E, Branduardi P, Lang C, Porro D, Ferrer P, Tutino ML, Mattanovich D, Villaverde A. Protein folding and conformational stress in microbial cells producing recombinant proteins: a host comparative overview. Microb Cell Fact. 2008;7:11.

6. Hoffmann F, Rinas U. Stress induced by recombinant protein production in Escherichia coli. Adv Biochem Eng Biotechnol. 2004;89:73-92.

7. Grabherr R, Nilsson E, Striedner G, Bayer K. Stabilizing plasmid copy number to improve recombinant protein production. Biotechnol Bioeng. 2002;77:142-7.

8. Striedner G, Pfaffenzeller I, Markus L, Nemecek S, Grabherr R, Bayer K. Plasmid-free T7-based Escherichia coli expression systems. Biotechnol Bioeng. 2010;105:786-94.

9. Mairhofer J, Scharl T, Marisch K, Cserjan-Puschmann M, Striedner G. Comparative transcription profiling and in-depth characterization of plasmid-based and plasmid-free Escherichia coli expression systems under production conditions. Appl Environ Microbiol. 2013;79:3802-12.

10. Kudla G, Murray AW, Tollervey D, Plotkin JB. Coding-sequence determinants of gene expression in Escherichia coli. Science. 2009;324:255-8.

11. Ow DS, Lee DY, Tung HH, Lin-Chao S. Plasmid regulation and systemslevel effects on Escherichia coli metabolism. In: Lee SY, editor. Systems biology and biotechnology of Escherichia coli. Berlin: Springer; 2009. p. 273.

12. Rahmen N, Schlupp CD, Mitsunaga H, Fulton A, Aryani T, Esch L, Schaffrath U, Fukuzaki E, Jaeger KE, Büchs J. A particular silent codon exchange in a recombinant gene greatly influences host cell metabolic activity. Microb Cell Fact. 2015;14:156

13. Mittal P, Brindle J, Stephen J, Plotkin JB, Kudla G. Codon usage influences fitness through RNA toxicity. Proc Natl Acad Sci USA. 2018;115:8639-44.

14. Rinas U, Tsai LB, Lyons D, Fox GM, Stearns G, Fieschko J, Fenton D, Bailey JE. Cysteine to serine substitutions in basic fibroblast growth factor: effect on inclusion body formation and proteolytic susceptibility during in vitro refolding. Bio/Technology. 1992;10:435-40.

15. Hoffmann F, van den Heuvel J, Zidek N, Rinas U. Minimizing inclusion body formation during recombinant protein production in Escherichia coli at bench and pilot plant scale. Enzyme Microb Technol. 2004;34:235-41.

16. Li Z, Nimtz M, Rinas U. Global proteome response of Escherichia coli BL21 to production of human basic fibroblast growth factor in complex and defined medium. Eng Life Sci. 2017;17:881-91.

17. Kwon SK, Kim SK, Lee DH, Kim JF. Comparative genomics and experimental evolution of Escherichia coli BL21(DE3) strains reveal the landscape of toxicity escape from membrane protein overproduction. Sci Rep. 2015;5:16076.

18. Schlegel S, Genevaux P, de Gier JW. De-convoluting the genetic adaptations of E. coli $C 41(D E 3)$ in real time reveals how alleviating protein production stress improves yields. Cell Rep. 2015;10:1758-66.

19. Starosta AL, Lassak J, Jung K, Wilson DN. The bacterial translation stress response. FEMS Microbiol Rev. 2014;38:1172-201.

20. Estapé $D$, Rinas U. Folding kinetics of the all- $\beta$ sheet protein human basic fibroblast growth factor, a structural homolog of interleukin-1 $\beta$. J Biol Chem. 1999;274:34083-8.

21. Li Z, Kessler W, van den Heuvel J, Rinas U. Simple defined autoinduction medium for high-level recombinant protein production for T7-based Escherichia coli expression systems. Appl Microbiol Biotechnol. 2011;91:1203-13.

22. Knoerzer W, Binder HP, Schneider K, Gruss P, McCarthy JEG, Risau W. Expression of synthetic genes encoding bovine and human basic fibroblast growth factors (bFGFs) in Escherichia coli. Gene. 1989;75:21-30.

23. Crameri A, Whitehorn EA, Tate E, Stemmer WP. Improved green fluorescent protein by molecular evolution using DNA shuffling. Nat Biotechnol. 1996;14:315-9.

24. Puigbo P, Bravo IG, Garcia-Vallve S. CAlcal: a combined set of tools to assess codon usage adaptation. Biol Direct. 2008;3:38. 
25. Kayser A, Weber J, Hecht V, Rinas U. Metabolic flux analysis of Escherichic coli in glucose-limited continuous culture: I. Growth rate dependent metabolic efficiency at steady state. Microbiology. 2005;151:693-706.

26. Candiano G, Bruschi M, Musante L, Santucci L, Ghiggeri GM, Carnemolla B, Orecchia P, Zardi L, Righetti PG. Blue silver: a very sensitive colloidal Coomassie G-250 staining for proteome analysis. Electrophoresis. 2004;25:1327-33.

\section{Publisher's Note}

Springer Nature remains neutral with regard to jurisdictional claims in published maps and institutional affiliations.
Ready to submit your research? Choose BMC and benefit from:

- fast, convenient online submission

- thorough peer review by experienced researchers in your field

- rapid publication on acceptance

- support for research data, including large and complex data types

- gold Open Access which fosters wider collaboration and increased citations

- maximum visibility for your research: over 100M website views per year

At BMC, research is always in progress.

Learn more biomedcentral.com/submissions 